\title{
“Gendering” European Security: Policy Changes, Reform Coalitions and Opposition in the OSCE
}

Anne Jenichen (Aston University, UK),

Jutta Joachim (Radboud University, Netherlands),

Andrea Schneiker (University of Siegen, Germany)

\begin{abstract}
The OSCE has rarely been considered in scholarship on gender and security, even though it was one of the regional security organisations whose gender policy predated the United Nations Security Council's call for more international attention to issues related to women, peace and security in October 2000. Based on an analysis of official OSCE documents and on semistructured interviews, we trace the integration of gender issues in the OSCE and explore the rationale behind and the challenges associated with it. We identify two phases of gender policy change in the OSCE and show how the integration of UNSCR 1325 brought about an expansion of OSCE gender policy from an exclusive focus on "soft" security issues towards increased inclusion of gender in the area of "hard" security. Drawing on historical and feminist institutionalism, we argue that reform coalitions were crucial for the policy changes in the OSCE but that they encountered institutional and ideational barriers, which hampered implementation of the gender policy. In light of rising opposition, our analysis warns of a backlash that might jeopardise current achievements.
\end{abstract}

Keywords: Organisation for Security and Co-operation in Europe (OSCE); gender; UN Security Council Resolution 1325 (UNSCR 1325); women, peace and security; historical institutionalism; feminist institutionalism

The authors would like to thank the Folke Bernadotte Academy (Sweden) for its financial support. 


\section{Introduction}

Gender issues have not been a top priority in regional security organisations. An important international development facilitating change in this regard has been Resolution 1325 on Women, Peace and Security, which the United Nations (UN) Security Council adopted in October 2000 (hereafter "UNSCR 1325") and which it followed up with another seven resolutions between 2008 and 2015, generating the UN's Women, Peace and Security Agenda. For the first time in its history, the UN Security Council created rules on the participation of women in peace and security processes and the prevention of and protection from sexual violence in the context of armed conflicts that are binding for all UN member states. Most regional organisations, including the North Atlantic Treaty Organisation (NATO) and the European Union (EU), have started to implement UNSCR 1325 and to integrate gender issues into their security policies (Barnes 2011, Coissard and Perrin-Bensahel 2014, Guerrina and Wright 2016, Kronsell 2016, Joachim, Schneiker and Jenichen 2017, Wright 2016). Another regional security organisation has largely been neglected in this emerging field of research: the Organisation for Security and Co-operation in Europe (OSCE). This is surprising for two reasons: Firstly, the OSCE is the largest regional security organisation worldwide. The now 57 member states (in OSCE terminology referred to as "participating states") form a geographic realm reaching, according to the OSCE's slogan, "from Vancouver to Vladivostok" and including the whole of Europe, the South Caucasus, Central Asia, Russia and North America. Secondly, it belongs to the few regional organisations that had already introduced gender issues into its security policy before UNSCR 1325 was adopted.

The institutionalisation of gender in the OSCE, i.e. the creation and implementation of new rules on gender equality through the adoption of gender policy documents and the appointment of gender advisers, has not received much academic attention yet. The still scarce research on gender within the OSCE has focused exclusively on specific aspects, such as the role of middle 
management in driving the implementation of the Women, Peace and Security Agenda, particularly on the ground in Southeast Europe, despite opposition from some participating states (Lukatela 2016), and the assessment of the OSCE's 2004 Gender Action Plan (Watson 2007). Important empirical contributions notwithstanding, a longer-term perspective explaining the development of the OSCE's gender policy is still missing. The objective of our study, therefore, is to provide such a perspective, one that can shed light not only on the factors that are conducive to gender mainstreaming, but also on those that hamper its implementation in a regional security organisation. In addition, by illuminating internal organisational dynamics, our analysis makes a more general contribution to the research on international (security) organisations, a field in which the OSCE still is an under-researched subject.

Drawing on historical and feminist institutionalism and based on a qualitative analysis of official documents and semi-structured interviews, we explore the processes that led to the adoption of the OSCE's gender policy in general, and the organisation's efforts to implement UNSCR 1325 in particular. Our findings demonstrate how the implementation of UNSCR 1325 instigated a turn away from the exclusive consideration of gender in the human dimension of the OSCE's comprehensive concept of security, i.e. in the area of human rights, election observation, freedom of the press, minority issues, the rule of law, tolerance and nondiscrimination (often also referred to as "soft" security), and towards increased inclusion of gender in the politico-military dimension, including arms control, border management, conflict prevention and resolution, counter-terrorism, policing, and security sector reform (which we will refer to as "hard" security later on). ${ }^{1}$ In addition, our analysis not only shows that reform coalitions that pushed for the strengthening of the OSCE's gender policy have been crucial for organisational change, it also points to the institutional and ideational barriers that these

\footnotetext{
${ }^{1}$ In total, the OSCE's comprehensive concept of security consists of three dimensions. In addition to the two dimensions mentioned, it also includes the economic and environmental dimension (e.g. sustainable economic growth and international economic cooperation to counter security threats, cooperation on environmental issues to prevent conflict) (for more information, refer to the OSCE's website: www.osce.org).
} 
coalitions have encountered. It reveals that while coalition members did not at first face much internal resistance to the gendering of security policies, a backlash resulting from rising opposition to the concept of gender appears likely in the foreseeable future.

In the remainder of this article, we proceed as follows. First, we theoretically conceptualise causes of change within international organisations based on historical and feminist institutionalism and explain the methodology of our study. Then, we discuss how gender issues were introduced in the OSCE. We identify two phases of institutionalisation: The first phase, which began at the end of the 1990s and lasted until 2004, concentrated on the introduction of gender issues into the organisation. During that phase, gender activities focused primarily on the human dimension of the OSCE's comprehensive security policy. The second phase, which started in 2005 , has been characterised by a broader integration of gender issues into the other dimensions as well, initiated in part by the gradual implementation of UNSCR 1325. For each phase, we analyse the reform coalitions that advocated changes and the institutional constraints they encountered, leading to a discussion of whether a third phase, characterised by stagnation, is looming. We conclude with some reflections on the theoretical implications of our findings and their likely consequences for the politics on gender both within the OSCE and in Europe more broadly.

\section{Change within International Organisations}

In the area of International Relations, change within international organisations (IOs) is often explained using one or more of three approaches: principal-agent models, bureaucratic accounts and historical institutionalism. In this section, we briefly introduce each of these approaches, arguing that historical institutionalism, in combination with its feminist variant, is the most appropriate for our analysis of gender policy change within the OSCE because it transcends the exclusive focus on just one group of actors and their specific type of motivation 
that is prevalent in the other two approaches, and because it considers different degrees of change.

Proponents of principal-agent models assume that states delegate authority to IOs to achieve common goals, focusing on whether and how states (the principals) control change within IOs (the agents). Change, according to this model, takes place if the preferences of (powerful) member states change and if these member states then use bargaining to persuade the others to follow the new direction (see e.g. Hawkins et al. 2006).

Bureaucratic accounts, by contrast, focus on the bureaucracies of IOs as autonomous actors and as likely catalysts - or preventers - of internal change. Focusing on rules and routines, bureaucracies control knowledge and information, and they learn. They develop a certain culture that drives and also may, in the long run, change their behaviour. However, this behaviour is not always efficient; as Barnett and Finnemore (2004) note, it can also result in dysfunctional or pathological patterns of action (see also Weaver 2008).

Lastly, historical institutionalism works from the assumption that changes often occur incrementally rather than radically, because institutions, understood as "'rules of the game' the rules, norms, and practices - that structure political, social, and economic life" (Chappell and Waylen 2013, p. 599), are change-resistant. One reason for this is the dynamic of increasing returns, which are defined as "the costs of switching from one alternative to another [that] will, in certain social contexts, increase markedly over time" (Pierson 2000, p. 251). If actors have invested in existing institutional designs, and if they are afraid that they might lose benefits they are currently enjoying if the institutional design were to change, then, rather than investing in radical change, they tend to stick to existing institutions, even if these institutions have become ineffective. This becomes particularly likely if decision-making structures, such as the consensus rule in force in the OSCE, allow small groups or even individual member states to block reforms (Hanrieder 2014). In such cases, organisations may experience lock-in effects if 
“(i)nstitutions [...] lock in balances of power or policy paradigms for lengthy periods of time and thus give those in privileged positions [...] a stake in protecting extant designs" (Fioretos 2011, p. 377).

In addition to vested interests, ideas embedded in institutions can also act as a constraint in an organisation and prevent new ideas from gaining legitimacy (Hall 1993). Feminist institutionalists, for instance, have called attention to the difference between formal and informal institutions and to the fact that institutions are inherently gendered. Constructions of masculinity and femininity - that is, notions of how women and men are and should be, and what roles they should or should not assume-are embedded in the logics of political institutions, which constrain and shape social interaction (Mackay, Kenny and Chappell 2010, p. 580). Informal norms and rules that disadvantage women have proved to be persistent, despite attempts by feminist reformers to challenge them. They exist alongside and in conjunction with formal institutions and are the reason "changes to formal rules do not always mean that institutions act in ways designers anticipated or wanted, as informal norms, rules, and procedures are very powerful—particularly in terms of gender-and may undermine formal changes" (Chappell and Waylen 2013, p. 603). Gender equality policies, therefore, can only unfold their transformative potential if in addition to formal rules informal gender norms are altered as well. If gender equality is institutionalised only formally, implementation and effectiveness of ensuing policies are often limited, a situation that is quite common in security organisations due to entrenched masculinist norms and practices (see, for example, Kronsell 2016 on the EU). The military and the police are premised on gendered norms and practices characterised by a reinforcement of paternalistic masculinities - men as protectors of allegedly powerless women and children — and the exclusion of women. Although the formal rules for women's access to the police and the armed forces have changed practically everywhere and the numbers of women in these institutions have increased as a result, "norms related to 
masculinity remain embedded in the organizations and their practices and become a challenge for women's inclusion and performance" (Kronsell 2016, p. 515).

According to historical institutionalists, two conditions must be met for change to occur in IOs despite the entrenched nature of institutions: there must be internal reform coalitions that push for change, and these must interact with external actors or be members of external networks. Internal reform coalitions prepare the ground within the organisation, and interaction with external actors allows for new ideas to enter the organisation and create pressure to abandon or modify existing practices (Hanrieder 2014, Moschella and Vetterlein 2014). If pushing for gender equality, such reform constellations are akin to "velvet triangles" that Woodward (2003) observed in the EU's internal affairs. They consist of feminist actors from (1) state organisations, including member states and the organisation's bureaucracy, as well as (2) activists from civil society and (3) experts from outside of the organisation, who constantly push for the introduction of gender into the organisation's policy-making. Similar constellations have been crucial in overcoming obstacles to the integration of gender equality issues into the security policies of regional organisations, such as the EU and NATO (Joachim, Schneiker and Jenichen 2017, Wright 2016). However, lacking support by many member states, weak leadership on some parts of the organisation's bureaucracy, little participation of explicitly feminist civil society organisations and the persistence of norms that exclude women from the sphere of "hard" security have so far prevented the development of a strong feminist "velvet triangle" and of effective gender mainstreaming in the EU's Common Security and Defence Policy and in NATO (Guerrina and Wright 2016, Kronsell 2016, Wright 2016).

Seeking to contribute to this emerging literature on the institutionalisation of gender issues in regional security organisations, our analysis draws primarily on historical institutionalism, including its feminist variant, and Woodward's concept of "velvet triangles" to identify factors that have promoted or hampered the development of the OSCE's gender policy. Going beyond 
the exclusive focus of principal-agent models and bureaucratic accounts on either member states or IO bureaucracies, we explore both internal (member states and IO bureaucracy) and external influences (other IOs, NGOs, experts), as well as the institutional impediments that these reform coalitions encountered.

Our investigation is based primarily on a qualitative analysis of OSCE documents (1996-2016), including gender policy documents and evaluation reports, reports from official meetings related to gender, annual reports, and relevant statements by OSCE delegations. Some of these documents were publicly available on the OSCE website, others we obtained through the OSCE archive in Prague. We systematically reviewed all documents with regard to information on gender policy processes in the organisation to identify relevant events, gender policies, the main actors involved and the organisation's official view points on issues of gender. To fill information gaps left open by the documents, particularly with regards to the interaction between actors and "unofficial" views on gender policies, we complemented the document analysis with ten semi-structured interviews with former and current OSCE officials (six from the internal bureaucracy and one from a delegation) and three representatives of civil society involved in these processes at one point or another to obtain more information on the formation of reform coalitions, their activities and the opposition that they encountered. Four of these interviews had already been conducted in 2002 and 2003 within the context of a student project by one of the authors which analysed the introduction of gender issues in the OSCE (i.e. it used the same question underlying this article), the other six interviews were conducted in 2015 and 2016; some of them in Vienna in person and others, with interviewees not based in Vienna (anymore), via telephone, Skype or e-mail. One caveat is that we did not manage to talk to opponents of the OSCE gender policy (due to unanswered interview requests). For information on tacit opposition, therefore, we had to rely on what our interviewees, all of them supporters of the OSCE's gender policy, told us rather than on first-hand accounts by sceptics themselves. 
Still, the document analysis and the interviews taken together provide us with a comprehensive picture of how the gender policy in the OSCE has evolved.

\section{"Gendering" the OSCE: Policy Change, Advocacy and Opposition}

In the following sections, we focus on the two phases during which the OSCE institutionalised gender within the organisation. In both phases, reform coalitions were crucial. However, they looked differently and encountered different institutional dynamics, which affected their activities and success.

\section{The First Phase (mid-1990s-2004): Introducing Gender Issues into OSCE Polity and Policy}

The first phase was characterised by the introduction of gender issues to the organisation. At the end of the 1990s, two gender advisers were appointed, one in the OSCE General Secretariat in Vienna and another one in the OSCE's Office for Democratic Institutions and Human Rights (ODIHR) in Warsaw. These gender advisers have since been responsible for advising political bodies of the OSCE on questions of gender mainstreaming, protection from discrimination and sexual harassment, and equal opportunities within the organisation (gender adviser in Vienna), as well as for developing a coherent approach to gender equality and the integration of a gender perspective into all of ODIHR's activities in participating states (Gender Adviser in Warsaw, together with the ODIHR Gender Unit, which was established in 2001). Under the aegis of this new gender bureaucracy, the OSCE adopted its first Gender Action Plan in June 2000 (OSCE 2000), a few months before the UN Security Council adopted Resolution 1325 . The plan called for the protection from discrimination and sexual harassment within the organisation, gender training for new staff, monitoring of how participating states implement OSCE gender equality commitments and the consideration of a gender dimension in the planning of new field operations, among other things. In 2004, a new Gender Action Plan, that is still in force today, 
replaced the first one (OSCE 2004). This new plan, although structured similarly, is considerably more comprehensive and detailed than the first, resulting primarily from the specification of previous objectives and demands and a far more explicit assignment of responsibilities to concrete actors in the organisation, including annual reporting on the plan's implementation by the Secretary General.

Prior to these developments, the OSCE's predecessor, the Conference for Security and Cooperation in Europe $(\mathrm{CSCE})^{2}$, had already recognised the importance of equality between women and men for a just and democratic society in its 1991 Moscow Document (Shvedova 2012), though without any practical consequences. This eventually changed in the mid-1990s, when a Swiss-led reform coalition started to advocate gender issues within the organisation. Switzerland, for example, proposed at the Review Meeting in Vienna in 1996 women's issues as the topic for the next human dimension seminar (OSCE 1996). ${ }^{3}$ This seminar, on "The Promotion of Women's Participation in Society”, became the very first gender-related activity of the OSCE. It took place in Warsaw in October 1997 and was concluded with a number of recommendations on how the OSCE's participating states and the OSCE itself might become more active in promoting women. These recommendations included a call for the creation of a position that would be responsible for coordinating gender issues and gender mainstreaming within the organisation (OSCE/ODIHR 1997).

The Secretary General of the OSCE responded to this call in May 1998 by appointing the then Diplomatic Adviser as Focal Point for Gender Issues. Subsequent to her appointment, she became a major supporter of the introduction of gender issues into the organisation. One of her main interests was to create a full position that would be responsible for gender issues, both

\footnotetext{
${ }^{2}$ The CSCE was founded in 1975 to provide a forum for consultations and negotiations between governments of the Eastern and Western blocs. It was transformed into a formal organisation, the OSCE, in 1995.

${ }^{3}$ At each implementation meeting on the human dimension, ODIHR organises a seminar on one issue area in the human dimension of security. The topics for these seminars are proposed and selected by state delegations.
} 
because of the double burden resulting from the two functions she now performed in the organisation and because she felt that she lacked expertise in the area of gender issues. ${ }^{4}$

A few other OSCE delegations, including Denmark and Norway, supported Switzerland's call for more awareness for gender issues. Some even provided funding to facilitate institutional changes: Luxembourg, for example, for a temporary position to assist the above mentioned Focal Point, the United Kingdom to second the Gender Adviser to be based at ODIHR in Warsaw and Switzerland itself to second the Gender Adviser in the OSCE Secretariat until these two advisory positions were transformed into contractual ones, funded since then from the OSCE's general budget. ${ }^{5}$

From a theoretical point of view, Switzerland's efforts highlight that one member state alone, even a small one, may be able to make a difference if it manages to garner sufficient support among its peers. This example also sheds light on the variety of interests that can motivate states to push for change. For Switzerland this interest was reputation-building. Its efforts were a good opportunity to gain more visibility at the international level, since in the 1990s, the OSCE was the only multilateral venue for Switzerland to attend to the state's security interests and to contribute to stability in Europe (Wenger 1997). ${ }^{6}$

Another internal supporter of Switzerland's efforts, besides the OSCE delegations mentioned earlier, was the OSCE Parliamentary Assembly whose then President organised a meeting of female parliamentarians on "The Role of Women in Connection with the OSCE's ConflictPreventive Activities" at the Seventh Annual Session of the OSCE Parliamentary Assembly in Copenhagen in July 1998. The parliamentarians, for instance, encouraged the Secretary

\footnotetext{
${ }^{4}$ Interview, Vienna, 22 October 2002.

${ }^{5}$ Interviews, Vienna, October 2002.

${ }^{6}$ The OSCE was the only intergovernmental security organisation of which Switzerland was a member at that time. The decision to join NATO's Partnership for Peace programme was still pending, and membership of the UN followed later, in 2002.
} 
General to commission an action plan on gender issues, to be prepared by the focal point, and to introduce gender training for OSCE staff (OSCE Parliamentary Assembly 1998).

The advocates of gender issues within the organisation cooperated with external supporters from civil society, which provided important expertise and networking opportunities. For example, the Swiss Peace Foundation "swisspeace" participated in the preparation of the human dimension seminar in October 1997 and prepared a position paper for one of the working groups. To follow up on the seminar's recommendations, the organisation then started to organise roundtables on women's issues. These roundtables were attended by Swiss politicians, interested members of the OSCE bureaucracy and experts from other NGOs involved in the process, such as the Swiss-based international NGO Women's International League for Peace and Freedom (WILPF) and the European office of Human Rights Watch. ${ }^{7}$ During the 1990s, the OSCE involved representatives from these NGOs as speakers, rapporteurs, and chairs of working groups in meetings and conferences on gender issues. They were also invited to meetings that NGOs were normally not allowed to attend, and it was during these meetings that they reiterated many of the demands that the OSCE realised later, such as the establishment of a Gender Adviser at the Secretariat, the introduction of gender training and the preparation of an action plan (OSCE/ODIHR 1997, 1998, OSCE 1999). Points of reference in these meetings were events in the OSCE region, such as the mass rapes during the wars in Bosnia and Herzegovina and in Croatia, and the involvement of Italian OSCE staff in Kosovo in forced prostitution. These events can be understood as exogenous shocks that, according to historical institutionalists, serve as important triggers of institutional change (Fioretos 2011, p. 376). Later, representatives of NGOs and a number of IOs also participated in the development of the OSCE's gender policy. For example, they were involved in the Informal Working Group on Equal Opportunities for Women and Men, formed in 1999, in

\footnotetext{
${ }^{7}$ Interviews with civil society actors, 16 December 2002 and 23 April 2003.
} 
which interested delegations and the Gender Advisers discussed, evaluated and extended the policy.

This reform coalition, consisting of members of OSCE delegations (most prominently Switzerland, Denmark, Luxembourg, Norway and the UK), of the Parliamentary Assembly and, since its establishment, the newly formed OSCE gender bureaucracy, as well as activists and experts from civil society, formed a "velvet triangle" which successfully pushed for the introduction of gender issues into the OSCE.

Beyond the appointment of two gender advisers and the adoption of two Gender Action Plans, these changes included gender-neutral job descriptions and the invitation of women to apply, the introduction of a gender module into the regular induction course for new staff and the development of appropriate training materials, and the regular collection of genderdisaggregated data. Units within the Secretariat appointed Gender Focal Points, and both the OSCE Chairperson-in-Office and the Parliamentary Assembly appointed Special Representatives on Gender Issues. ODIHR incorporated a gender dimension into its various projects and programmes, including election observation operations, an anti-trafficking programme, rule-of-law projects and monitoring activities, and implemented gender projects in ten participating states in Northern and Southeast Europe, the Southern Caucasus and Central Asia. OSCE field operations also appointed gender focal points, some of whom integrated activities for the promotion of gender equality and women's rights into their projects (OSCE Annual Reports 2000, 2001).

However, the effects of these changes during the first phase remained limited. Firstly, all these activities focused almost exclusively on the human dimension of security - that is, on the area of democracy promotion and human rights (OSCE Annual Reports 1998-2004). Secondly, representation of women at senior and policy-making levels continued to be low and "gender advisers and focal points [were not] sufficiently involved in the development of new policies 
and programmes" (OSCE 2004, pp. 2-3). As Watson (2007, p. 397) observed in her evaluation of the second Gender Action Plan, "the process of gender mainstreaming within the OSCE has been neither generalized nor systematic. Where it has happened, it has been more the result of individual initiatives, rather than institutional momentum".

These developments are exemplary of the dynamics that historical and feminist institutionalists have pointed out: Vested interests in previous institutional designs, embedded ideas and informal institutions prevent radical changes by hampering the effective implementation of newly established rules. According to our interviewees, open opposition against the new gender policy was limited during this phase, but tacit resistance became manifest in the policy's limited implementation. Lacking willingness of many participating states to earmark additional funding, e.g. for establishing the gender bureaucracy in the first place ${ }^{8}$, and lacking political will to effectively implement the second Gender Action Plan (Watson 2007), point to vested interests in existing designs and to persistent views of gender issues as circumstantial in the area of security. The exclusive focus on just one, namely the human dimension of security, also suggests the persistence of gender norms which construct "hard" security as a masculine sphere. The comprehensive conceptualisation of security within the OSCE, on the one hand, facilitated the acceptance of gender issues as relevant for security, but, on the other hand, enabled their relegation to "soft" security issues. The politico-military dimension, by contrast, remained almost untouched by gender issues. This gradually changed when the OSCE started to implement UNSCR 1325.

\section{The Second Phase (since 2005): Integrating Gender Issues More Comprehensively}

The second phase of gender policy change in the OSCE was primarily characterised by the broadening of the policy. Gender-related activities in the economic dimension of security

\footnotetext{
${ }^{8}$ Interviews, Vienna, October 2002.
} 
increased and issues of violence against women and of gender mainstreaming became increasingly important, as illustrated by the adoption of the Ministerial Council Decisions on Preventing and Combating Violence against Women (2005 and 2014) and on Promoting Equal Opportunity for Women in the Economic Sphere (2011), as well as by several handbooks, toolboxes and guidelines on gender mainstreaming and a project on engaging men (OSCE Annual Reports 2005-2015).

Most notably, gender issues also became integrated into the politico-military dimension. In 2005, the OSCE adopted the Ministerial Council Decision on Women in Conflict Prevention, Crisis Management and Post-Conflict Rehabilitation (OSCE 2005), a stated aim of which was to integrate UN commitments following from UNSCR 1325 into the OSCE's own obligations and activities and to increase women's participation in OSCE institutions and field missions, particularly in senior positions, in peacebuilding initiatives, and in processes of conflict prevention, conflict resolution, and post-conflict rehabilitation. Since then, the OSCE has organised a wide variety of events, such as conferences, workshops, seminars, roundtables and panel discussions, as well as side events at official OSCE meetings, on issues related to the Women, Peace and Security Agenda. It has also published a range of handbooks and toolkits on such issues as gender and security sector reform, gender-responsive mediation and internal oversight within armed forces and the police. Other activities referred to the support of reforms and the provision of training on women's representation and gender mainstreaming in the police, the armed forces and border security agencies, and to direct contributions to the development of National Action Plans for the implementation of UNSCR 1325 in participating states (Ormhaug 2014, pp. 34-37, OSCE Annual Reports 2005-2015). As a result, the percentage of projects in the politico-military dimension with gender equality as the principal objective rose from close to zero in 2005 to 11 per cent in 2015 (OSCE 2016, p. 8). In 2011, the institutional structure of the Secretariat was changed accordingly; the Senior Gender 
Adviser became a position at the ambassadorial level and was complemented by three Gender Advisers, each responsible for one security dimension.

The integration of UNSCR 1325 into OSCE policy was advocated by a Swedish-led reform coalition. The Swedish Delegation, prior to tabling the Ministerial Council Decision, organised an OSCE expert seminar on "Women in Conflict Prevention and Crisis Management", which took place in Vienna in June 2005, in order to promote the Resolution in the OSCE (Folke Bernadotte Academy 2005, OSCE Delegation of Sweden 2005). This seminar was attended by the UN Secretary-General's Special Adviser on Gender Issues and the Advancement of Women, who reported on the UN's experiences with the implementation of UNSCR 1325, and by representatives from many participating states, OSCE field operations and other IOs and NGOs.

The Swedish Delegation was supported mainly by the Folke Bernadotte Academy, a Swedish government agency for peace, security and development, which helped organise the seminar in 2005 and provided funding for the Swedish secondment of the Gender Adviser for the politico-military dimension in the OSCE Secretariat. Another supporter was the Vice-President and Special Representative for Gender Issues of the OSCE Parliamentary Assembly, who as a former Vice-Chairperson of the Defence Committee of the Swedish Parliament was particularly familiar with the difficulties involved in integrating gender issues into "hard" security. She shared her experience at several events, including a special panel discussion on "Women in Security Politics - Do Women Make a Difference?", organised by the Parliamentary Assembly in conjunction with the 50th session of the UN Commission on the Status of Women in New York (OSCE Annual Report 2006).

The leading role of Swedish actors in championing UNSCR 1325 in the OSCE is not surprising. Sweden has established itself as a leading supporter of gender mainstreaming in security policies, not only in the OSCE, but also in the EU and in NATO (Joachim, Schneiker and 
Jenichen 2017, Wright 2016). These activities are reflective of Sweden's strong equality values and gender mainstreaming agenda on the domestic level. The Swedish government, for instance, has made achieving equality of women and men a fundamental aim of its foreign policy ${ }^{9}$, and it was one of the first governments worldwide to adopt a National Action Plan on UNSCR 1325. Advocacy for UNSCR 1325 in the OSCE was an implementation strategy that complemented the preparation of this plan (NGO Working Group on Women, Peace and Security 2005, p. 63).

Many participating states actively supported Sweden's efforts to make UNSCR 1325 more effective within the OSCE, among them the Norwegian and Irish Delegations which expressly endorsed the tabled Ministerial Council Decision in their statements (OSCE Delegation of Ireland 2005, OSCE Delegation of Norway 2006). Switzerland also continued to be an important promoter of gender equality issues within the organisation; for example, in 2014, the Swiss Chair-in-Office supported the organisation of a large conference to review the progress of the OSCE's gender policy and also initiated discussions on its amendment (OSCE 2016, p. 97). In addition, Finland, France, Germany, Spain, Austria, Serbia and the US were listed as supportive delegations by our interviewees.

After the adoption of the 2005 Ministerial Council Decisions on UNSCR 1325 and on violence against women (which referred to UNSCR 1325 as well), facilitated by staff changes within the OSCE's gender bureaucracy, the new Gender Advisers in the Secretariat and in ODIHR's human rights department became active supporters and internal networkers for the implementation of UNSCR $1325 .{ }^{10}$ Since her appointment in 2011, the Gender Adviser for the politico-military sphere has assumed a leading role within the OSCE bureaucracy for the

9 See the website of the Swedish government on its gender equality policies: http://www.government.se/government-policy/gender-equality/ (last access on 27 November 2017).

${ }_{10}$ Telephone interviews, July and August 2016. 
implementation of UNSCR 1325, confirming Lukatela's (2016) finding that middle management staff in IOs are important drivers of the Women, Peace and Security Agenda.

However, the change the Swedish-led internal reform coalition achieved was quite incremental, in that, unlike the EU and NATO, no Regional Action Plan or any other specifically tailored policy for the integration of UNSCR 1325 into OSCE gender policy was adopted. Instead, the Ministerial Council Decision of 2005 mainly called for the proactive implementation of the OSCE Gender Action Plan and only secondly demanded the integration of relevant parts of UNSCR 1325 into the OSCE's activities. The Decision also focused exclusively on the one issue that was also prioritised in OSCE gender policy at that time - namely, to increase participation and representation of women on all levels of decision-making, ${ }^{11}$ while disregarding the aspect of integrating a gender perspective into all conflict- and crisis-related activities. $^{12}$

Historical institutionalism helps us to understand why the formal institutionalisation of UNSCR 1325 in the OSCE was rather incremental and inward-looking. For one, there was only limited external interaction. Even though the new Gender Advisers frequently exchanged information and best practices with other IOs, including the UN, NATO, the Council of Europe and the EU (OSCE Annual Reports 2006-2015, OSCE 2010), confirming how important it is for internal change coalitions to be embedded in external networks, cooperation with civil society organisations was limited. In contrast to the first phase, by the 2000 s, following the establishment of the gender bureaucracy within the OSCE, acquiring external expertise from civil society no longer seemed as necessary as it had before. NGOs have been invited to OSCE

\footnotetext{
${ }^{11}$ Our review of OSCE Annual Reports shows that almost half of the gender activities implemented by OSCE institutions between 1996 and 2000 and more than a third of those implemented between 2001 and 2004 referred to the promotion of the participation of women, primarily in the political sphere, but also in the public, societal and economic spheres (this analysis excludes anti-trafficking activities, because although trafficking is often regarded as an issue of violence against women and as another outcome of the integration of gender issues into the OSCE, we consider the organisation's anti-trafficking agenda to be separate from its gender mainstreaming agenda given that human trafficking is not exclusively a gender issue).

${ }^{12}$ The aspect of prevention of and protection from violence against women was covered by the Ministerial Council Decision on violence against women of the same year, which mentioned UNSCR 1325 also only in passing.
} 
events, sometimes also as speakers (OSCE 2015b), but have rarely been involved in joint projects. ${ }^{13}$ Exceptions include two projects concerning the development of UNSCR 1325 National Action Plans in participating states that involved as project partners the Peace Research Institute Oslo (PRIO), an independent research foundation, and Inclusive Security, an international NGO founded by the former United States Ambassador to Austria, who had already been involved in advocating gender issues in the OSCE region in the 1990s (Hunt 1997, Ormhaug 2014, OSCE and Inclusive Security 2016). More systematic cooperation on UNSCR 1325 with civil society actors has been taking place only within participating states, primarily through ODIHR. ${ }^{14}$ The reform coalition advocating UNSCR 1325 in the OSCE, consequently, resembled more an internal reform coalition than a "velvet triangle" as it consisted primarily of some participating states (most prominently Sweden, Norway, Ireland and Switzerland), parts of the OSCE Parliamentary Assembly and the internal gender bureaucracy. Even though the latter exchanged experiences with other IOs, there was no close cooperation with (feminist) civil society organisations. Instead, the OSCE relied primarily on internal expertise which impeded new ideas and external pressures to enter the organisation.

Moreover, the fact that the OSCE relied on existing internal policy frameworks and practices rather than introducing new ones also resulted from the persistence of ideas concerning gender policy already embedded in the organisation, which constrained support from more conservative actors. ${ }^{15}$ Although UNSCR 1325 was not openly opposed at first, and although gender issues even received increased institutional support (as evidenced by the fact that more resources were made available to the gender bureaucracy), according to some of our interviewees, there was a lack of understanding and awareness within the OSCE as to why it

\footnotetext{
${ }^{13}$ Interviews, Vienna, 04 November 2015, and via telephone, 15 December 2015.

14 Telephone interview, 04 August 2016.

${ }^{15}$ Our interview partners were reluctant to disclose who these sceptics were. The OSCE documents available to us did not reveal this information either. Therefore, we can only speculate that, based on their open opposition later, the Holy See and Russia were among them.
} 
was important to add UNSCR 1325 to the existing gender policy. Facilitated by the established practices of OSCE gender policy at that time, many, for example, regarded gender issues as "soft" issues that did not belong to the politico-military dimension of "hard" security issues. Another widespread perception, highlighted by some of our interviewees, was that the resolution was related exclusively to the UN and its peacekeeping mandate, whereas the OSCE was focusing primarily on post-conflict activities and did not mandate military operations. ${ }^{16}$ This scepticism was probably also nurtured by the overall similarity between the OSCE's second Gender Action Plan (OSCE 2004) and UNSCR 1325 (UN 2000). For instance, both associate "gender" with "women", call for the participation of women in conflict resolution and management, acknowledge women's agency in relation to peace and security matters, utilise functional arguments on women's participation (e.g. to make peace, security and stability more sustainable), and call for the protection from and prevention of violence against women and for the mainstreaming of gender in conflict-related activities. However, as mentioned, the OSCE Gender Action Plan had in the past been implemented primarily in the human dimension of security. The 2005 Ministerial Council Decision, therefore, was important to create momentum for the extension of the OSCE's gender policy to the politico-military dimension. The sceptics' arguments revealed opposition against exactly this move, indicating deep-seated notions of "hard" security as a masculine sphere in which gender issues were deemed irrelevant, rather than an endorsement of the already existing gender policy of the OSCE.

Although almost all participating states are also member states of the $\mathrm{UN}^{17}$ and had endorsed the resolution, it was still perceived at first as an "outside" idea that had difficulties making its way into the OSCE. This scepticism helps to explain why the Ministerial Council Decision of

\footnotetext{
${ }^{16}$ Interviews, Vienna, November 2015, and via telephone, December 2015, July and August 2016.

17 The only exception is the Holy See, which is a full member of the OSCE but has only consultative status at the UN.
} 
2005 that formally integrated UNSCR 1325 into OSCE policy remained rather vague and focused primarily on the existing OSCE gender policy rather than on the resolution itself. Because some participating states were reluctant to regard UNSCR 1325 as relevant to the OSCE, the then Gender Adviser at first, rather than using UNSCR 1325, preferred to use the OSCE's "own" concept of comprehensive security, which comprised both "hard" and "soft" security issues, to make a case for the inclusion of gender issues in all three dimensions. ${ }^{18}$ The above shows that, as with the first phase, a reform coalition was crucial for gender policy change to happen during the second phase. However, unlike the coalition of the first phase, this second coalition relied more on internal expertise and frameworks and encountered internal scepticism that limited the extent of formal change it was able to achieve. If scepticism evolves into open opposition, stagnation is a likely outcome, as the next section will demonstrate.

\section{A Third Phase Looming? Recent Opposition to Further Gender Policy Development}

Despite a number of remaining challenges, the institutionalisation of gender in the OSCE has raised awareness within the organisation and led to some material success. For example, the share of women in senior management positions went up from 15 per cent in 2004 to 35 per cent in 2015 (OSCE 2016, p. 17). A large review conference on its gender policy, organised by the OSCE in 2014, showed substantial progress in the field of gender equality within the organisation (OSCE 2014). However, this and other reviews have also revealed a number of weaknesses that continue to exist. The percentage of women in the politico-military dimension, for instance, is still fairly low, ranging from 8 per cent in civilian police to 11 per cent in the area of military affairs (OSCE 2016, p. 115). Another problem is the lack of clear baselines and indicators for measuring and monitoring, and thus more effectively evaluating, success (OSCE 2016, p. 115, see also Vesa and van der Leest 2012). In response, gender advocates

\footnotetext{
${ }^{18}$ Interview, Vienna, 05 November 2015.
} 
within the OSCE have pushed for further extensions to the OSCE's gender policy to include two major reform projects: the revision of the Gender Action Plan and the adoption of a Regional Action Plan for the implementation of UNSCR 1325. However, numerous attempts of several OSCE Chairmanships to negotiate and adopt such changes have failed because of opposition to it, particularly from the Holy See and Russia. In recent years, the consensus rule of OSCE decision-making has turned out to be a major obstacle to any further development of the OSCE's gender policy.

The 2004 Gender Action Plan needs revision in order to adapt it to the evolving international political environment and to include lessons the organisation has learned in recent years. Some of our interviewees disclosed to us that supporters of the gender policy in the OSCE have been concerned that negotiations of a completely new Gender Action Plan might lead to a backlash on existing achievements, due to opposition from some of the participating states. ${ }^{19}$ These supporters have therefore opted for an addendum to the 2004 Gender Action Plan, the purpose of which is to update and complement the existing document (see also OSCE 2016). At the 2014 Ministerial Council, it was primarily the Delegation of the Holy See that obstructed the adoption of such an addendum (Lukatela 2016, p. 53).

The Holy See has repeatedly questioned the definition of gender equality and gender mainstreaming used in the OSCE, arguing that there is no international agreement on the definition, that "gender" is not socially constructed and that men's and women's roles in society are attributed by the divine (Lukatela 2016, pp. $51 \mathrm{f}$.). Recently, the Holy See has distanced itself from the view of gender equality that emphasises equality and autonomy, stressing instead differences and complementarity between women and men (Vatican Radio 2016). As a consequence, the Holy See has always had reservations about gender issues in the OSCE, and the many interpretive statements attached to relevant Ministerial Council Decisions attest to

\footnotetext{
${ }^{19}$ Interview, Vienna, 05 November 2015, and via telephone, 15 December 2015.
} 
that. For instance, the Holy See has often expressed its opposition to the mentioning of the Convention on the Elimination of All Forms of Discrimination Against Women (CEDAW) on the grounds that it was not a "consensus document" given that the Holy See is not a member of the UN and therefore has not signed CEDAW (Lukatela 2016, p. 50), and the same holds true for the Beijing Platform for Action, the final document of the Fourth World Conference on Women, organised by the UN in 1995.

Another issue is the still missing Regional Action Plan concerning UNSCR 1325 and its follow-up resolutions to develop clear benchmarks for the implementation of the Women, Peace and Security Agenda in the OSCE. The 2005 Ministerial Council Decision's limited scope and specificity provide a weak basis for the implementation of UNSCR 1325 and its follow-up resolutions (Lukatela 2016). For this reason, participants in the OSCE Security Days in 2015, a conference dedicated that year to the issue of gender, recommended "that the OSCE develop its own action plan to integrate the Women, Peace and Security agenda more efficiently into the OSCE policies" (OSCE 2015a, p. 7). In the past, this has been prevented by the OSCE Delegation of the Russian Federation.

Russia argues that gender equality has already been achieved and that other issues are more pressing, such as children's rights and the specific needs of men, whose rights, the Russian Delegation alleges, have been ignored in the discourse on gender equality (Lukatela 2016, p. 52). The Russian Delegation is particularly critical of the OSCE's activities regarding UNSCR 1325, claiming that it "is applicable only in certain situations", disagreeing "with its excessive promotion in the OSCE and especially its extremely broad interpretation" and, therefore, taking the position "that the leading role in this regard should remain with the United Nations" (OSCE Delegation of the Russian Federation 2016, p. 2). Since 2014, the Russian Delegation has blocked several attempts to negotiate an Action Plan on the Women, Peace and Security Agenda (Lukatela 2016, p. 53). In contrast to the Holy See, whose opposition is 
primarily a result of disagreement on particular values, the "Russian motivation is likely linked to the utility it sees in using gender equality to push back against the overall human rights agenda and the human dimension work where it encroaches on Russian interests" (Lukatela 2016, p. 57). From a rationalist perspective, Russia's stance might be regarded as sustaining an existing tradition of "avoidance" of key human rights concerns by non-Western participating states in the OSCE, with an interest to shut down discussion of controversial issues and obscure human rights problems in their own countries (Murray 1997). However, Russia's position also reveals a historical dimension. The OSCE's predecessor, the CSCE, and its human rights agenda had been instrumental in bringing the Soviet regime down (Thomas 2001), suggesting that Russian reluctance to address the human dimension of security within the scope of the OSCE might also have historical reasons.

Recent developments in the OSCE are an excellent example of a "lock-in effect" due to institutional impediments to attempts of reform coalitions to push for policy change. Such coalitions still continue to try to craft policies that advance gender equality within the organisation and the OSCE region. However, their capabilities to do so are considerably constrained by institutional structures such as the consensus rule, which, in combination with emerging opposition, has hampered any further development of the OSCE's gender policy in recent years.

\section{Conclusions}

Gender issues in general and UNSCR 1325 in particular have become firmly established within the OSCE's security policy thanks to reform coalitions that have advocated these policy changes and ensured that they would be sustained. Not only has the group of gender issue supporters within the organisation grown over the years to include a larger number of sympathetic states, but the OSCE's gender bureaucracy has expanded as well, both in terms of 
human and financial resources, with increasing influence on the organisation's policies in many areas. However, changes have often been hampered by less supportive participating states, empowered by the consensus rule in force in the OSCE, by persistent gender norms based on the exclusion of women, by embedded ideas concerning gender policies and - sometimes - a lack of external interaction with civil society actors. These impediments contribute to an explanation of why gender mainstreaming in the OSCE, despite formal changes, has not been as transformative as desired by its supporters.

Our results primarily support a historical and feminist institutionalist explanation of change in regional security organisations. In our view, the openness of this explanation as regards actor constellations and its emphasis of reform coalitions and institutional impediments to change, such as opportunity structures for external interaction, internal decision-making structures, embedded ideas and gendered norms, assist us best in explaining the development of the OSCE's gender policy. Internal actors, such as supportive representatives of member states and committed bureaucratic agents, as well as external actors from civil society and other IOs are important parts of reform coalitions, which, if they consistently push for the inclusion of gender into policy-making, are akin to Woodward's "velvet triangles".

Two more specific insights follow from our findings: On member states, our analysis demonstrates that even small states within an IO can make a difference. Not only can they hamper change under the consensus rule (as the Holy See has done), they can trigger change if they, jointly with committed agents from the bureaucracy and civil society, are able to garner enough support among member states and persuade them to address and decide on a specific matter (as in the cases of Switzerland and Sweden). States might also promote or impede change for different reasons - for example, because they want to increase their visibility and recognition in an IO (as in the case of Switzerland), or because they want to introduce their own national values to an IO (as in the case of Sweden), or because it is in their national interest 
to avoid controversial debates of the domestic situation (as in the case of Russia). Depending on whether or not a state regards gender mainstreaming as beneficial for promoting its broadly defined - interests in an IO, it will either endorse it or decide to resist such change.

On IO bureaucracies, our findings highlight their internal heterogeneity. Committed bureaucratic agents can be important parts of a reform coalition, while other parts may be reluctant to the proposed change. They also act as gatekeepers when it comes to access of external advocates of change, although such agents also have the option of approaching member states to get access, as some Swiss NGOs did in the 1990s. The specific roles and degrees of autonomy of bureaucratic agents within these "velvet triangles" would merit further research to better understand their specific potentials and constraints as important drivers of the Women, Peace and Security Agenda in regional security organisations.

On a more practical level, it is safe to say that the OSCE's gender policy has been relatively successful despite remaining challenges. It has helped raise awareness of gender issues both within OSCE institutions and in the OSCE's participating states and has contributed to an increase in the share of women in senior management positions and to the incorporation of a gender perspective into many parts of the organisation's security policy. However, many challenges remain. The OSCE and its participating states are still far from fully achieving gender equality. Moreover, the policy is not supported by all participating states, and some might even attempt to backtrack on previous commitments. If a "counter"-coalition were to emerge in the course of the current rise of right-wing anti-feminist forces in Europe and North America, this could compromise the leading role of the OSCE with regard to gender issues in security, which would lead to stagnation or even regression. Only if gender advocates within the OSCE and their external supporters can form a strong "velvet triangle" and persuade opponents that gender mainstreaming can be beneficial in furthering a variety of interests, including in becoming recognised as important part of the OSCE's security community, will 
they be able to safeguard the OSCE's leading role in this area. Otherwise, gender equality issues in the OSCE region are at risk of being drowned out by geopolitical conflicts between Russia and "the West".

\section{References}

Barnes, K., 2011. Turning policies into action? The European Union and the implementation of UNSCR 1325. In: 'F. Olonisakin, K. Barnes and E. Ikpe, eds. Women, peace and security: translating policy into practice. Abingdon: Routledge, 211-222.

Barnett, M., and Finnemore, M., 2004. Rules for the world: international organizations in global politics. Ithaca, NY: Cornell University Press.

Chappell, L., and Waylen, G., 2013. Gender and the hidden life of institutions. Public Administration, 91(3), 599-615.

Coissard, S., and Perrin-Bensahel, L., 2014. Women and conflicts: the adaptation of UN 1325 Resolution in the European Union. In: R. Bellais, ed. The evolving boundaries of defence: an assessment of recent shifts in defence activities. Bingley: Emerald, 201-218.

Fioretos, O., 2011. Historical institutionalism in international relations. International Organization, 65 (2), 367-399.

Folke Bernadotte Academy, 2005. Report from the expert seminar "Women in Conflict Prevention and Crisis Management”, 20 June 2005, Vienna, Austria [online]. Stockholm, $\begin{array}{llll}\text { Folke } & \text { Bernadotte } & \text { Academy. }\end{array}$ https://polis.osce.org/file/16251/download?token=oafkdggS [Accessed 3 September 2017].

Guerrina, R., and Wright, K. A. M., 2016. Gendering normative power Europe: lessons of the Women, Peace and Security agenda. International Affairs, 92 (2), 293-312. 
Hall, P. A., 1993. Policy paradigms, social learning, and the state: the case of economic policymaking in Britain. Comparative Politics, 25 (3), 275-296.

Hanrieder, T., 2014. Gradual change in international organisations: agency theory and historical institutionalism. Politics, 34 (4), 324-333.

Hawkins, D. G., et al., 2006. Delegation under anarchy: states, international organizations, and principal-agent theory. In: D. G. Hawkins, et al., eds. Delegation and agency in international organizations. Cambridge: Cambridge University Press, 3-38.

Hunt, S., 1997. Women's vital voices: the costs of exclusion in Eastern Europe. Foreign Affairs, 76 (4), 2-7.

Joachim, J., Schneiker, A., and Jenichen, A., 2017. External networks and institutional idiosyncrasies: the Common Security and Defence Policy and UNSCR 1325 on women, peace and security. Cambridge Review of International Affairs, 30(1), 105-124.

Kronsell, A., 2016. Sexed bodies and military masculinities: gender path dependence in EU's Common Security and Defense Policy. Men and Masculinities, 19 (3), 311-336.

Lukatela, A., 2016. Implementing the Women, Peace and Security Agenda in the OSCE: the power of middle management norms in the policy process. Security and Human Rights, $27(1-2), 45-58$.

Mackay, F., Kenny, M., and Chappell, L., 2010. New institutionalism through a gender lens: towards a feminist institutionalism? International Political Science Review, 31(5), 573-588.

Moschella, M., and Vetterlein, A., 2014. International organizations and organizational fields: explaining policy change in the IMF. European Political Science Review, 6 (1), 143-165.

Murray, M., 1997. The language of avoidance: how human rights issues are constrained by the rhetoric of non-Western participants in the organization for security and cooperation in Europe. International Legal Perspectives, 9 (1-2), 227-255. 
NGO Working Group on Women, Peace and Security, 2005. From local to global: making peace work for women: Security Council Resolution 1325 - five years on report [online]. New York, NGO Working Group on Women, Peace and Security. Available from: http://www.peacewomen.org/sites/default/files/fiveyearsonreport.pdf $\quad$ [Accessed 3 September 2017].

Ormhaug, C., 2014. OSCE study on national action plans on the implementation of the United Nations Security Council Resolution 1325 [online]. Vienna, Organization for Security and Co-operation in Europe. Available from: http://www.osce.org/secretariat/125727?download=true [Accessed 3 September 2017].

OSCE, 1996. Review meeting 1996, Vienna, 4-22 November 1996, Lisbon, 25-29 November 1996, reports by the rapporteurs (unpublished).

OSCE, 1999. Supplementary implementation meeting on gender issues, Vienna, 14-15 June 1999, final report, ODIHR.GAL/24/99, 24 June 1999.

OSCE, 2000. Action plan for gender issues, SEC.GAL/12/00/Rev.7, 1 June 2000.

OSCE, 2004. Action plan for the promotion of gender equality, MC.DEC/14/04, 7 December 2004.

OSCE, 2005. Decision No. 14/05: Women in conflict prevention, crisis management and postconflict rehabilitation, MC.DEC/14/05, 6 December 2005.

OSCE, 2010. The OSCE and "Women, Peace and Security": 10 years after the adoption of UNSCR 1325, High-Level Tripartite Meeting, Vienna, 14 June 2010 [online]. Available from: http://www.osce.org/gender/70694?download=true [Accessed 3 September 2017].

OSCE, 2014. Gender equality review conference report: outcomes and proceedings [online]. Vienna, OSCE. Available from: http://www.osce.org/secretariat/137761?download=true [Accessed 3 September 2017]. 
OSCE, 2015a. In pursuit of peace and security: how gender makes a difference: report from the OSCE Security Days, Vienna, 13 November 2015 [online]. Available from: http://www.osce.org/sg/216776?download=true [Accessed 3 September 2017].

OSCE, 2015b. In pursuit of peace and security: how gender makes a difference: annotated agenda. Vienna, 13 November 2015 [online]. Available from: http://www.osce.org/secretariat/198831?download=true [Accessed 3 September 2017].

OSCE, 2016. The Secretary General's 2015 annual evaluation report on the implementation of the 2004 OSCE action plan for the promotion of gender equality. Vienna, 2016 [online]. Available from: http://www.osce.org/secretariat/258281?download=true [Accessed 3 September 2017].

OSCE Annual Reports 1996-2015 [online]. Available from: http://www.osce.org.

OSCE Delegation of Ireland, 2005. Statement by the Minister of State for European Affairs on behalf of Ireland, Ministerial Council in Ljubljana, 5 December 2005 [online]. Available from: http://www.osce.org/mc/17248 [Accessed 3 September 2017].

OSCE Delegation of Norway, 2006. St.meld. nr. 11 (2005-2006): om samarbeidet i Organisasjonen for sikkerhet og samarbeid i Europa (OSSE) i 2005, Vienna [online]. Available from: https://www.regjeringen.no/no/dokumenter/stmeld-nr-11-2005-2006/id200109/?ch=1\&q= [Accessed 3 September 2017].

OSCE Delegation of Sweden, 2005. Statement by Sweden delivered by State Secretary for Foreign Affairs Hans Dahlgren, Ministerial Council in Ljubljana, 6 December 2005 [online]. Available from: http://www.osce.org/mc/17302?download=true [Accessed 3 September 2017].

OSCE Delegation of the Russian Federation, 2016. Statement by Mr. Alexander Lukashevich, Permanent Representative of the Russian Federation, at the 1092nd meeting of the OSCE 
Permanent Council, 10 March 2016 [online]. Available from: http://www.osce.org/pc/227906?download=true [Accessed 3 September 2017].

OSCE/ODIHR, 1997. Human dimension seminar on the promotion of women's participation in society, Warsaw, 14-17 October 1997, consolidated summary, ODIHR.GAL/14/97, 28 October 1997.

OSCE/ODIHR, 1998. Implementation meeting on human dimension issues, Warsaw, 26 October-6 November 1998, consolidated summary, ODIHR.GAL/58/98, 20 November 1998.

OSCE Parliamentary Assembly, 1998. Copenhagen Declaration of the Parliamentary Assembly of the Organization for Security and Co-operation in Europe, Copenhagen, July 1998 [online]. Available from: http://www.osce.org/pa/37870?download=true [Accessed 3 September 2017].

OSCE and Inclusive Security, 2016. Designing inclusive strategies for sustainable security: results-oriented national action plans on Women, Peace and Security [online]. Vienna, OSCE. Available from: http://www.osce.org/secretariat/294731?download=true [Accessed 3 September 2017].

Pierson, P., 2000. Increasing returns, path dependence, and the study of politics. American Political Science Review, 94 (2), 251-267.

Shvedova, N., 2012. The OSCE Copenhagen and Moscow documents: a short commentary on the OSCE's contributions to gender equality in political and public life. In: Institute for Peace Research and Security Policy at the University of Hamburg/IFSH, ed. OSCE Yearbook 2011. Baden-Baden: Nomos, 319-331.

Thomas, D. C., 2001. The Helsinki effect: international norms, human rights, and the demise of communism. Princeton, NJ: Princeton University Press.

UN, 2000. Security Council Resolution 1325, adopted at 4213th meeting, 31 October 2000. 
Vatican Radio, 2017. Holy See discusses migrants, environment, gender at OSCE, 15 January [online].

http://en.radiovaticana.va/news/2016/01/15/holy_see_discusses_migrants,_environment, gender_at_osce/1201150 [Accessed 3 September 2017].

Vesa, A., and Leest, K. van der, 2012. Towards a strategic approach in applying gendersensitive indicators: guidance for OSCE programming. In: Institute for Peace Research and Security Policy at the University of Hamburg/IFSH, ed. OSCE Yearbook 2011, BadenBaden: Nomos, 331-347.

Watson, N., 2007. From the inside out: The role of organizational change and capacity building in the promotion of gender equality in the OSCE. In: Institute for Peace Research and Security Policy at the University of Hamburg/IFSH, ed. OSCE Yearbook 2006, BadenBaden: Nomos, 388-403.

Weaver, C., 2008. Hypocrisy trap: The World Bank and the poverty of reform. Princeton, NJ: Princeton University Press.

Wenger, A., 1997. Die KSZE/OSZE als Brücke der Schweiz zur Mitgestaltung des europäischen Umfeldes. In: L. Goetschel, ed. Vom Statisten zum Hauptdarsteller: Die Schweiz und ihre OSZE-Präsidentschaft. Bern: Haupt, 9-28.

Woodward, A., 2003. Building velvet triangles: gender and informal governance. In Christiansen, T., and Piattoni, S., eds. Informal Governance in the European Union. Cheltenham: Edward Elgar, 76-93.

Wright, K. A. M., 2016. NATO's adoption of UNSCR 1325 on Women, Peace and Security: making the agenda a reality. International Political Science Review, 37 (3), 350-361. 